\title{
OPTICAL DATING OF SEDIMENTS IN KHARI RIVER BASIN AND SLIP RATE ALONG KATROL HILL FAULT (KHF), KACHCHH, INDIA
}

\author{
HIMANSU KUMAR KUNDU ${ }^{1}$, M. G. THAKKAR ${ }^{2}$, R. H. BISWAS ${ }^{3}$ and A. K. SINGHVI ${ }^{3}$ \\ ${ }^{I}$ Geochronology and Isotope Geology Division, GSI, 15, Kyd Street, Kolkata-700016, India \\ ${ }^{2}$ Department of Earth and Environmental Science, K.S.K.V. Kachchh University, Bhuj-370001, Gujarat, India \\ ${ }^{3}$ Geo-sciences Division, Physical Research Laboratory, Navrangpura, Ahmedabad-380009, Gujarat, India
}

\begin{abstract}
In the central region of Mainland Kachchh, Western India, the Katrol Hill Fault (KHF) is one of the major E-W trending faults. An understanding of the episodes of reactivation during the past has a bearing on the future seismicity in the region. These reactivations are manifested by offset of elevation of fluvial sediments and scarp-derived colluvium in the Khari River basin, SE of Bharasar $\left(23^{\circ} 11^{\prime} 36.5^{\prime \prime} \mathrm{N}, 69^{\circ} 35^{\prime} 22.6^{\prime \prime} \mathrm{E}\right)$. Stratigraphic offsets of the sediments at this site suggest three episodes of reactivation of the KHF during the late Quaternary. Optical dating of samples from sediment strata and top layer of scarp-derived colluvium using Natural Sensitivity Corrected - Single Aliquot Regenerative (NCF-SAR) protocol suggested that these events occurred during the past $\sim 30 \mathrm{ka}$, with the most recent historic episode around $3.0 \mathrm{ka}$. Given that a part of the slip recorded in the form of sediments offset, was lost due to erosion after faulting, a lower bound to the time averaged slip rate of the segment of KHF, is inferred to be $>0.23 \mathrm{~mm} /$ a during the past $30 \mathrm{ka}$.
\end{abstract}

Keywords: Slip rate, OSL dating, fluvial sediments, Kachchh.

\section{INTRODUCTION}

The Kachchh rift basin formed in early Mesozoic during the break up of Gondwana under a tensional tectonic regime. The rift - basin sediments were uplifted during the Tertiary under reverse tectonics after the collision of the Indian-Eurasian plates, (Biswas, 1977). The same forces were responsible for neotectonic movements and paleoseismicity in Kachchh during the Quaternary (Biswas and Khattri, 2002). The E-W trending Katrol Hill Fault (KHF) is a major range bounding intrabasinal fault that divides the Mainland Kachchh into northern and southern parts (Biswas and Despande, 1970; Fig. 1). The KHF created a major geomorphic divide in the form of Katrol hill range during the late Tertiary and Quaternary (Biswas, 1974), as a result of which Khari River descended from this range to the north into the plain of Banni (Fig.1). The KHF marks a sharp lithotectonic contact between Cretaceous and Jurassic formations particularly at fault zone and one such exposures of KHF is located at south of Bharasar in a stream section of Khari river basin (Thakkar et al., 1999; Patidar et al., 2007).

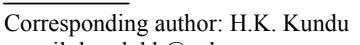

e-mail:kunduhk@yahoo.com

ISSN 1897-1695 (online), 1733-8387 (print) (C) 2010 GADAM Centre, Institute of Physics, Silesian University of Technology.

All rights reserved.
Quaternary sediments like bouldery colluvium, coarse sand and gravel, fluvial sand, lithified miliolitic sand and scarp derived colluvium are exposed in the river cliff showing offsets. The Quaternary period in Kachchh mainland is characterized by two tectonic episodes, the older one reactivated $\mathrm{E}-\mathrm{W}$ fault system and, the later triggered NNE-SSW, NE-SW, NW-SE and NNW-SSE trending transverse faults (Thakkar et al., 1999; 2006). Possibilities of reactivation of E-W trending KHF and its transverse faults in late Pleistocene has not been ruled out. Using ESR, Mathew et al. (2004) established reactivation of KHF at $70 \mathrm{ka}$ based on model ESR ages of gypsum precipitation along the fault plane from Satpura Dungar in the Katrol Hill Range (KHR). This is recalculated as $\sim 56 \mathrm{ka}$ using improved alpha efficiency values (Nagar et al., 2010).

Fault slip-rate and recurrence interval between earthquakes can be determined from offset measurements of related geomorphic markers like the alluvial fan deposits, deformed sediments, seismicities and other seismically affected sediments along with their dating e.g. luminescence dating (Mathew et al., 2006; Porat et al., 2007; Pucci et al., 2008; Fattahi et al., 2009). In recent years optically stimulated luminescence (OSL) technique of dating has been found to be reliable in determining ages 


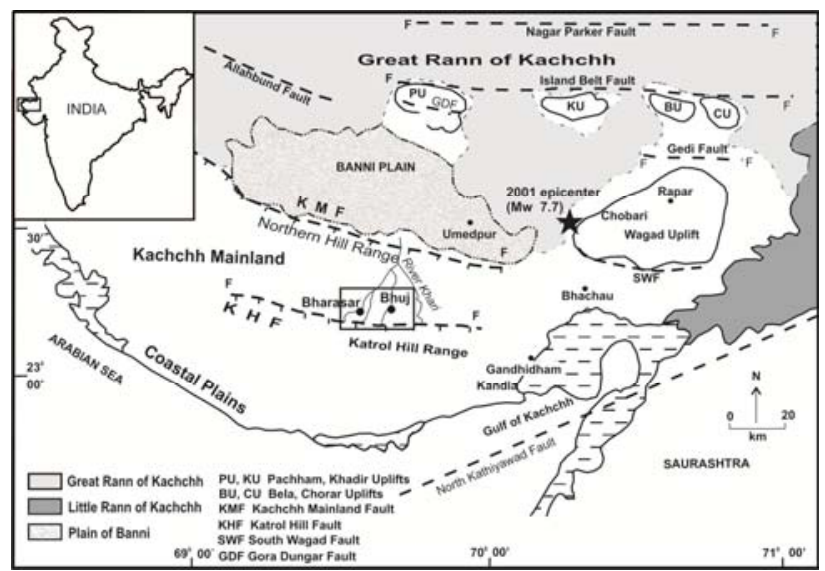

Fig. 1. Sample location map showing major faults and physiographic sub-divisions of Kachchh basin. Note the shaded parts are salt playas known as Ranns.

of such quaternary markers (Singhvi et al., 1994). The ages of quaternary deposits e.g. alluvial gravels, fine grained sediments and colluvial deposits associated with the Sabzevar thrust fault in North Eastern Iran were determined by using single-aliquot regeneration-dose (SAR) protocol of OSL method using quartz grains (Fattahi et al, 2006). Based on the OSL dates, the Holocene slip-rate of the Sabzevar thrust fault was estimated to be $\sim 1 \mathrm{~mm} / \mathrm{y}$. In another investigation based on the Infrared Stimulated Luminescence (IRSL from feldspars) dating of Shesh-Taraz river terrace deposition $(\sim 10 \mathrm{ka})$ associated with Doruneh fault, Central Iran, Fattahi et al. (2007) estimated the slip- rate of Doruneh fault to be $\sim 2.5 \mathrm{~mm} / \mathrm{y}$ and recurrence time between large earthquakes on the Doruneh fault to be $\sim 2000$ years. Another example of successful application of OSL dating is refining the slip-rate determination of the Anar fault, Central Iran. Cosmogenic ${ }^{10} \mathrm{Be}$ and OSL dating of cumulative offset of alluvial fan surfaces have yielded the long-term minimum slip-rate on the Anar fault to be $\sim 0.8 \mathrm{~mm} / \mathrm{y}$ (Le Dortz et al., 2009). OSL has also been applied to estimate Late Quaternary slip-rate by dating alluvial offsets caused by the active thrust faults, which bind the NW-trending massif, Baatar Hyarhan, in the Altai range of Western Mongolia (Nissen et al., 2009). The Late Quaternary (span $\sim 20 \mathrm{ka}$ ) vertical displacement rates across the NE and SW margins of Baatar Hyarhan were estimated to be $0.2-0.6 \mathrm{~mm} / \mathrm{y}$ (Zereg fault) and 0.1-0.4 $\mathrm{mm} / \mathrm{y}$ (Tsetseg fault) respectively. Besides these instances optically stimulated luminescence dating has been suitably applied to estimate the slip-rates of a number of other faults in different regions of the world e.g. the HarUs-Nuur fault (Mongolian Altai) (Nissen et al., 2009), Wellington fault near Wellington, New Zealand (Little et al., 2010), Duzce fault of the North Anatolian fault zone, Turkey (Pucci et al., 2008) and Dheshir fault, Central Iran (Fattahi et al., 2010 and references there in). The present study therefore aimed towards Optical dating of sediment offsets in a segment of the KHF near Bharasar in the Khari River basin to estimate slip-rate in the study area.

\section{GEOLOGICAL AND PALAEOSEISMICAL SIG- NIFICANCE OF THE SITE}

Samples were collected from Khari River cliff near Bharasar in the central part of Kachchh mainland $\left(23^{\circ} 11^{\prime} 36.5^{\prime \prime} \mathrm{N}, 6^{\circ} 35^{\prime} 22.6^{\prime \prime} \mathrm{E}\right.$, altitude $\left.132 \mathrm{~m}\right)$. KHF passes across the river and trends in NE-SW direction. The trajectory of streams in a seismically active region is modified by the nature of fault related deformation, geology and climate (Schumn, 1986). Apparent displacement and flexure in sediments are seen at the study site, and hence their optical dating was attempted to reconstruct the neotectonic and paleoseismic history. An upper bound to the age of these sediments was provided by underlying miliolite (sandy biomicrite) deposits with ${ }^{230} \mathrm{Th} /{ }^{234} \mathrm{U}$ ages in the range 130 to $30 \mathrm{ka}$, (Patidar et al., 2008; Baskaran et al., 1989). The cliff section at the site has $7 \mathrm{~m}$ thick Quaternary sediments and comprise, A) Bouldery colluvium, B) Gravelly sand, C) Coarse fluvial sand, D) Lithified miliolitic sand and E) Scarp-derived colluviums, (Fig. 2, Patidar et al., 2008 ). The KHF has been identified as a growth fault during the Quaternary and the splaying of the main fault strand has been noticed. Ground penetrating radar (GPR) investigations suggest changes in the nature of the fault during its upward propagation in younger sediments (Patidar et al., 2008). The gravelly clasts of unit A are oriented along a steepdipping fault plane prior to offset by the gentle SEdipping KHF. The top of unit A in the SE block is at $\sim 9 \mathrm{~m}$, while the same occurs at $\sim 2 \mathrm{~m}$ in the NE block (Fig. 2), which gives a total vertical offset of $\sim 7 \mathrm{~m}$ within the sediments overlapping the KHF (Patidar et al., 2008). The offset is along two faults (F1 and F2) with associated minor faults. We infer that the first movement occurred after the deposition of unit $\mathrm{A}$ and formed steeper fault (F1) due to the upward propagation of KHF. This was followed by the deposition of coarse fluvial sands in the middle, and gravels at the base and reworked fluvial miliolite (sandy biomicrite) with minor breaks in sedimentation (Units B, C and D, Fig 2). The second tectonic movement occurred after the deposition of unit $\mathrm{D}$ during which the second fault (F2) with a gentler dip was formed. The top most unit $\mathrm{E}$ comprises scarp-derived colluvium. Offset of this unit along both faults was the third faulting event. Various units described above had erosional bases. Major erosional contacts are, between units $\mathrm{A}$ and $\mathrm{B}$, and between $\mathrm{D}$ and $\mathrm{E}$ which mark phases of erosion and imply that presently available $7 \mathrm{~m}$ is a minimum estimate of the offset of the sediments. Samples location for Optical dating is given in (Fig. 3).

\section{METHOD AND INSTRUMENTATION}

Three samples (KHF-1, KHF-2 and KHF-3) were collected (Fig. 3) in metal pipes under dark room like conditions and, were sequentially treated in the laboratory with $1 \mathrm{~N} \mathrm{HCl}$ and $30 \% \mathrm{H}_{2} \mathrm{O}_{2}$ to remove carbonates and organic matters respectively. These were dried and sieved for 90$150 \mu \mathrm{m}$ sized grains. Quartz grains were then separated using a Frantz Magnetic separator and etched with 40\% $\mathrm{HF}$ for $80 \mathrm{~min}$ with constant magnetic stirring followed by a treatment with $12 \mathrm{~N} \mathrm{HCl}$ for $30 \mathrm{~min}$. The contamina- 


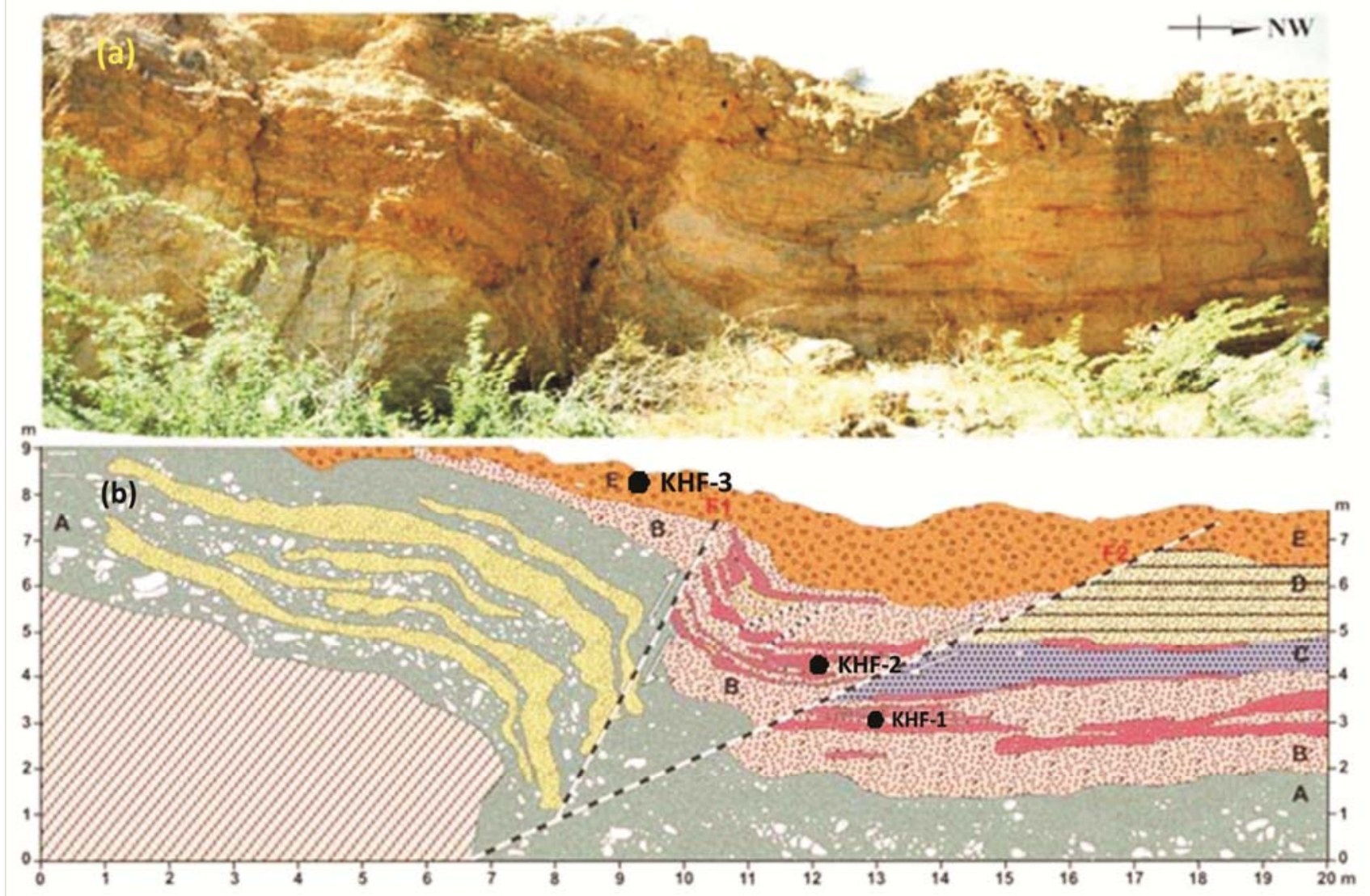

Fig. 2. a) Exposed cliff section along the Khari river to the SE of Bharasar showing offsetting in the Quaternary sediments. b) Overlay of cliff section showing various lithologies and faults: A) Bouldery colluvium, B) Gravelly sand, C) Coarse fluvial sand, D) Lithified miliolitic sand and E) Scarpderived colluvium. (from Patidar et al., 2008). Sample locations also shown.

tion of BGSL signal from feldspar grains was checked with infrared stimulated luminescence (IRSL) and samples indicating a contamination were re-etched using HF. The grains were deposited as a monolayer on stainless steel discs using Silko-Spray silicone oil. Typically discs contained $\sim \leq 100$ grains. Luminescence measurements were done on a RISO TL-DA-20 reader with blue LED source $(470 \pm 30 \mathrm{~nm})$. The detection optics comprised filters Hoya U-340 and Schott BG-39 coupled to an EMI 9835QA photomultiplier tube. Beta irradiations were carried out using an on-plate ${ }^{90} \mathrm{Sr} /{ }^{90} \mathrm{Y}$ beta source. The optically stimulated luminescence (OSL) measured at $125^{\circ} \mathrm{C}$ for 60 seconds. The equivalent dose $\left(\mathrm{D}_{\mathrm{e}}\right)$ was estimated using a modified version of the single aliquot regenerative dose (SAR) technique (Murray and Wintle, 2000; Murray and Wintle, 2003, Singhvi et al., 2010) with a preheat of $240^{\circ} \mathrm{C}$ for 10 seconds. Dose growth curves were constructed using three regeneration dose points and two points were used to estimate the recuperation effect and reliability of sensitivity corrections (recycling point) respectively. Regeneration doses of $45.3 \mathrm{~Gy}$, 90.5 Gy and 181.0 Gy were used for KHF-1 and KHF-2 samples and were 13.6 Gy, 27.2 Gy and 54.3 Gy for KHF-3. Preheat for both regenerative and test doses (10.86 Gy) were $240^{\circ} \mathrm{C}$ for 10 seconds and the recuperation signal was $<1 \%$ of natural OSL signal. Samples had recycling ratios between 0.9-1.1. A modification of the SAR protocol was in correcting for the sensitivity

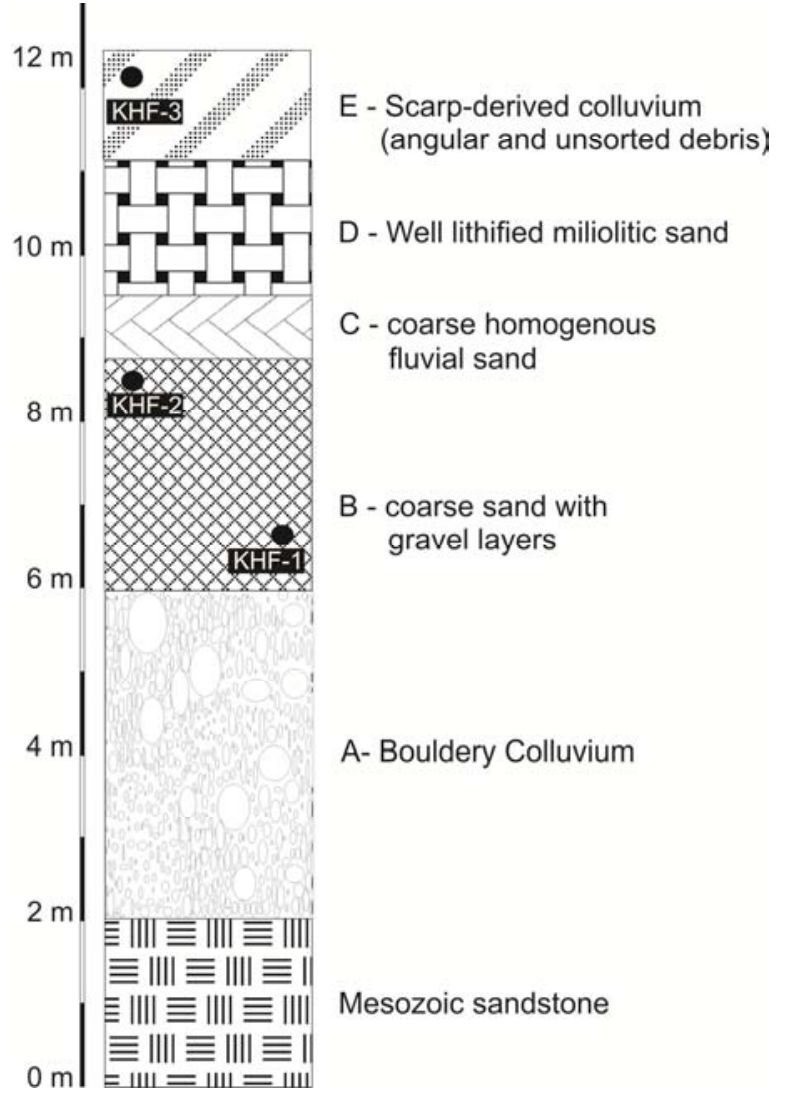

Fig. 3. Lithology of sediment strata with sample locations. 
change during the read out of natural BGSL. An additional measurement step was therefore introduced to correct for the sensitivity changes during the preheat and the OSL read out of the natural OSL. This was done by measuring the intensity of the $110^{\circ} \mathrm{C}$ TL glow peak to a test dose (10.86 Gy) before and after preheat and natural OSL measurement for each disc (Singhvi et al., 2010). This correction factor, termed Natural Sensitivity Correction Factor (NCF) was the ratio of the $110^{\circ} \mathrm{C}$ TL peaks of sample after and before the preheat and OSL read out and corrects for the sensitivity changes during the measurement of natural OSL. The NCF was used to rescale the natural intensity of the sample so that both the natural and regenerated curves were compared under identical sensitivity correction. The corrected natural intensity was used for estimating the SAR equivalent dose. Studies indicate that NCF could range from $0.7-1.3$ but in the present case it was nearer unity for the present samples. Representative SAR growth curves and OSL decay curves of the three samples KHF-1, KHF-2 and KHF-3 are shown in Fig. 4. The protocol for the SAR measurement incorporating the NCF procedure is given below:

1) Natural sample

2) Test dose $10.86 \mathrm{~Gy}$

3) $\mathrm{TL} 200^{\circ} \mathrm{C}(\mathrm{P} 1)$

4) Preheat $240^{\circ} \mathrm{C}, 10 \mathrm{~s}$

5) OSL $60 \mathrm{~s} @ 125^{\circ} \mathrm{C}\left(\mathrm{L}_{\mathrm{N}}\right)$

6) Test dose $10.86 \mathrm{~Gy}$

7) $\mathrm{TL} 200^{\circ} \mathrm{C}(\mathrm{P} 2)$

8) Preheat $240^{\circ} \mathrm{C}, 10 \mathrm{~s}$

9) OSL $60 \mathrm{~s} @ 125^{\circ} \mathrm{C}\left(\mathrm{T}_{\mathrm{N}}\right)$

10) Regeneration dose and normal SAR

The dose corresponding to natural point $\left(\mathrm{L}_{\mathrm{N}} / \mathrm{T}_{\mathrm{N}}\right)$ multiplied by $\mathrm{NCF}$ factor $\left(\mathrm{P}_{2} / \mathrm{P}_{1}\right)$ provided the equivalent dose +10.86 Gy (test doses used to measure sensitivity of samples as received and after OSL readout). This dose was subtracted to get the equivalent dose in each case. Individual equivalent doses $\left(D_{e}\right)$ were obtained from the fitting of the dose response curve with a single saturating exponential function. Dispersion in equivalent dose, can arise due to both, the partial bleaching and beta dose heterogeneity (arising from spatial distribution of hotspots, feldspar grains containing ${ }^{40} \mathrm{~K}$ beta emitters in the sediment matrix (Mayya et al., 2006) or carbonate cold spots (Jacobs et al., 2008). Given that carbonate in the matrix was low cold spots could be ignored. Beta dose heterogeneity for low $\mathrm{K}$ content samples is expected to be higher. Though beta dose heterogeneity is relevant to single grains only, we have considered it here as we used only small aliquots with about $<100$ grains per disc. Given that $<10 \%$ of these are bright, we are, in effect, looking at light sum from a few to $<10$ grains. We, therefore, calculated the ages using Mayya et al., 2006. According to the beta heterogeneity model age of a sample is given by;

$$
T=\frac{D_{\min }}{[f+\delta(1-f)] \dot{D}}
$$

where $\mathrm{D}_{\min }$ is the minimum equivalent dose and $\dot{D}$ is the corresponding dose rate. $\mathrm{D}_{\min }$ was computed as the

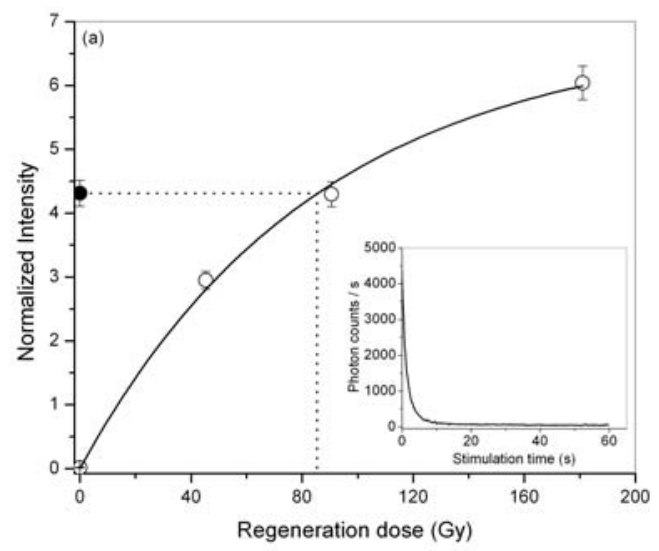

A

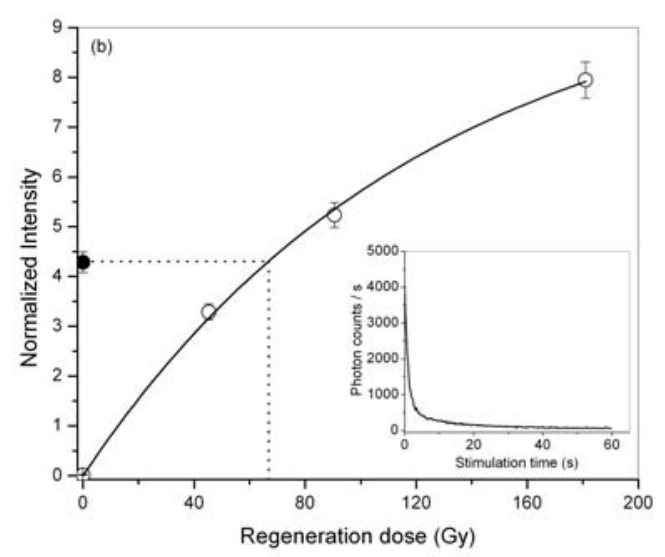

B

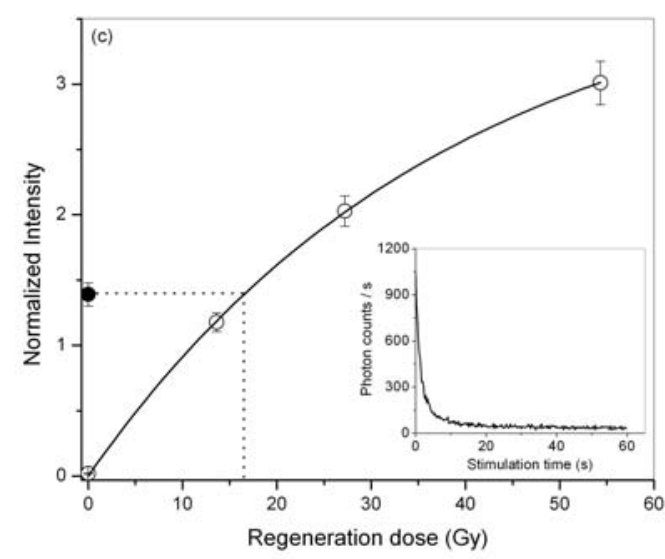

C

Fig. 4. Representative SAR growth curve and OSL decay curve of sample a) KHF-1 b) KHF-2 and c) KHF-3.

weighted average of dose values falling in between the least dose and least dose +2 sigma, where sigma is the error on the least value. Of the total dose rate, $f$ is the fraction corresponding to uniform dose distribution and $1-\mathrm{f}$ is the fraction of heterogeneous dose due to ${ }^{40} \mathrm{~K}$. We calculated $f$ using Gruen's age calculation program that is available with Riso readers. The values of $\mathrm{f}$ for KHF-1, KHF-2 and KHF-3 are $0.68,0.64$ and 0.62 respectively. $\delta$ depends on $\mathrm{K}$ concentration of the sample and the relation is, as described in Morthekai (2007): 


$$
\delta=0.46[1-\exp (-2.2 \times K)]
$$

The values of $\delta$ for three samples are 0.36, 0.41 and 0.42 respectively. Distribution of $D_{e}$ values for each sample is shown in the histograms (Fig. 5). Equivalent dose distributions for each sample have also been displayed as probability density functions or PD plots with individual aliquot $D_{e}$ values superimposed in ranked order along with their errors (Fig. 6). Radial plots of the distribution of $D_{e}$ values centered around the central $D_{e}$, are shown in Fig. 7.

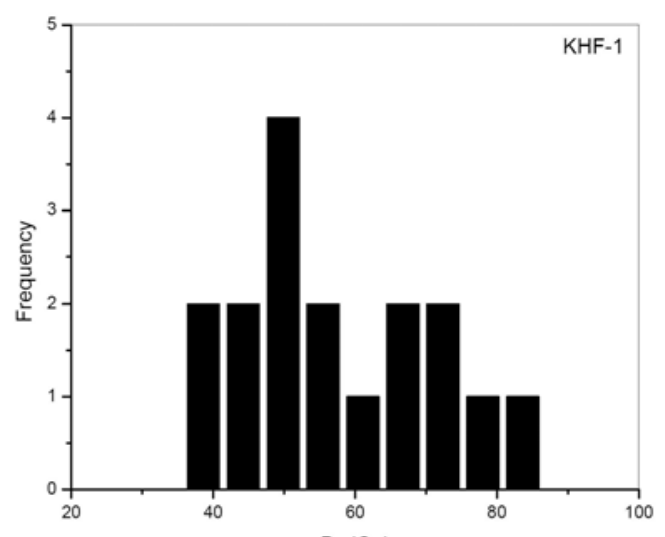

A

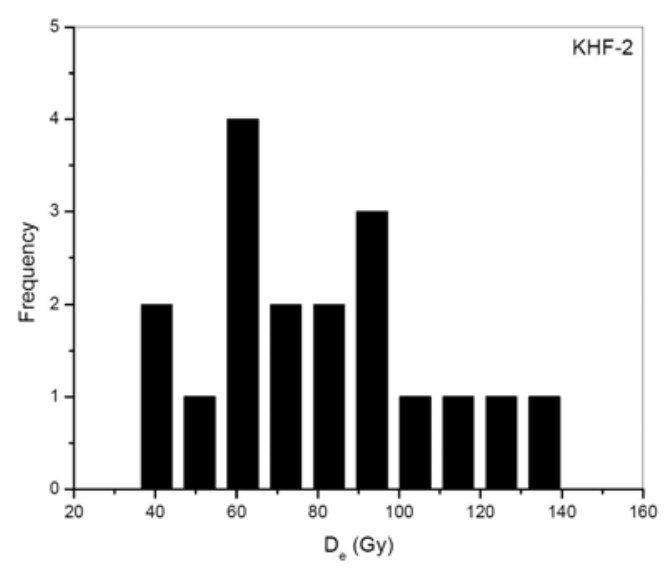

B

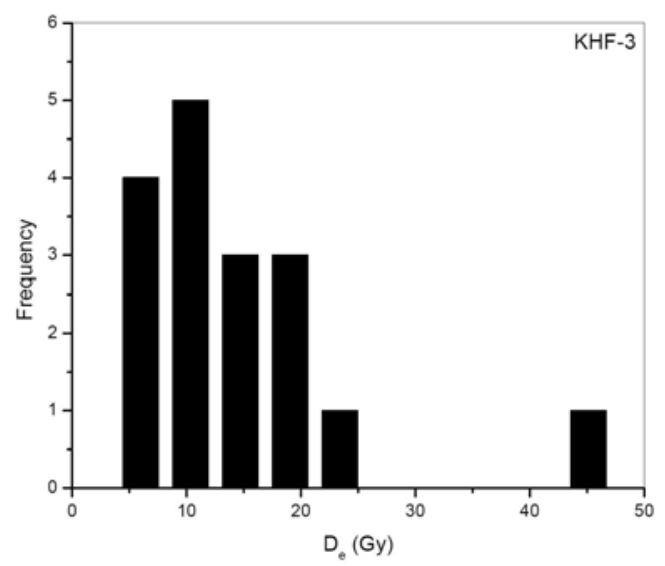

Fig. 5. Histogram showing distribution of $D_{e}$ values of sample a) KHF-1 (19 aliquots) b) KHF-2 (19 aliquots) and c) KHF-3 (17 aliquots).
The dose rate estimation used thick source $\mathrm{ZnS}(\mathrm{Ag})$ alpha counting for measurement of elemental concentration of $\mathrm{U}$ and $\mathrm{Th}$ and $\mathrm{NaI}(\mathrm{Tl})$ gamma ray spectrometry for $\mathrm{K}$ concentration. The annual dose rate was calculated using the conversion factors by Adamiec and Aitken, (1998) and a radioactive equilibrium in the decay chain was assumed. An average water content of $5 \%$ was assumed. The cosmic ray contribution to the dose rate was calculated according to Prescott and Hutton (1994). Table 1 provides the experimental data and age values based on different models.

\section{RESULTS}

The ages of KHF-1, KHF-2 and KHF-3 from the sediment layer B and scarp-derived colluvium layer E (Fig. 3), using beta heterogeneity model (Mayya et al., 2006), were $31.8 \pm 2.8 \mathrm{ka}, 28.5 \pm 3.7 \mathrm{ka}$ and $3.0 \pm 0.3 \mathrm{ka}$ respectively. If we used the central age model (CAM;

A
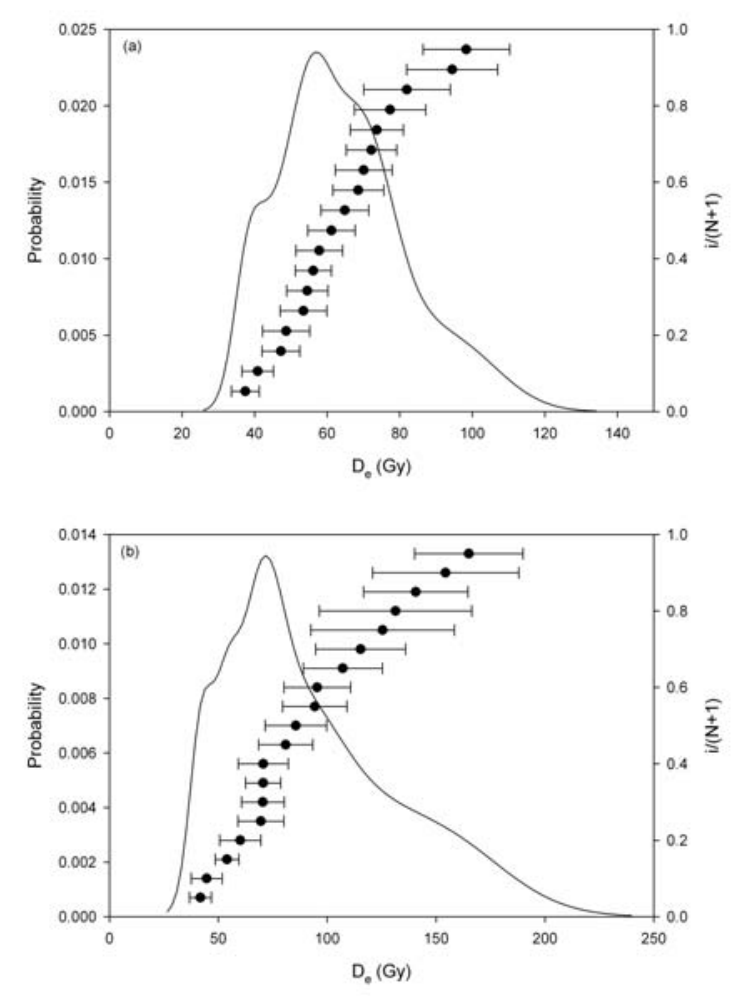

B

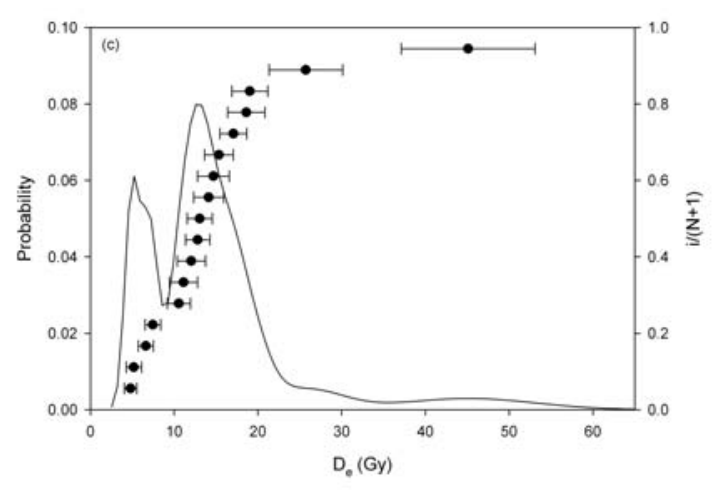

C

Fig. 6. Probability density distribution or PD plot with a ranked series of $D_{e}$ values and their errors for the sample a) KHF-1 b) KHF-2 and c) KHF-3. 


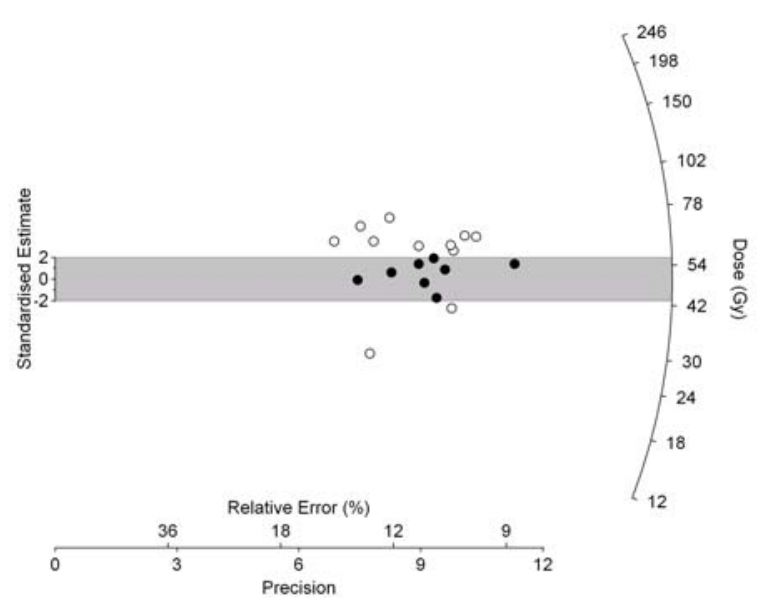

A

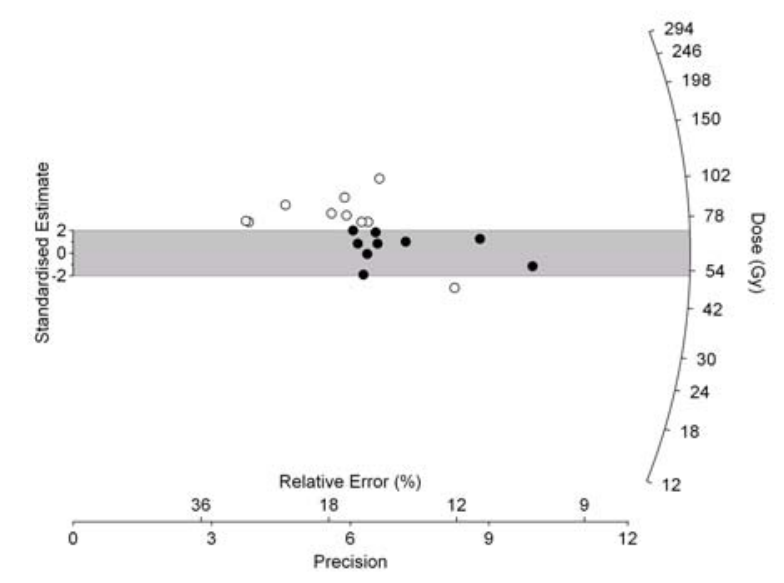

B

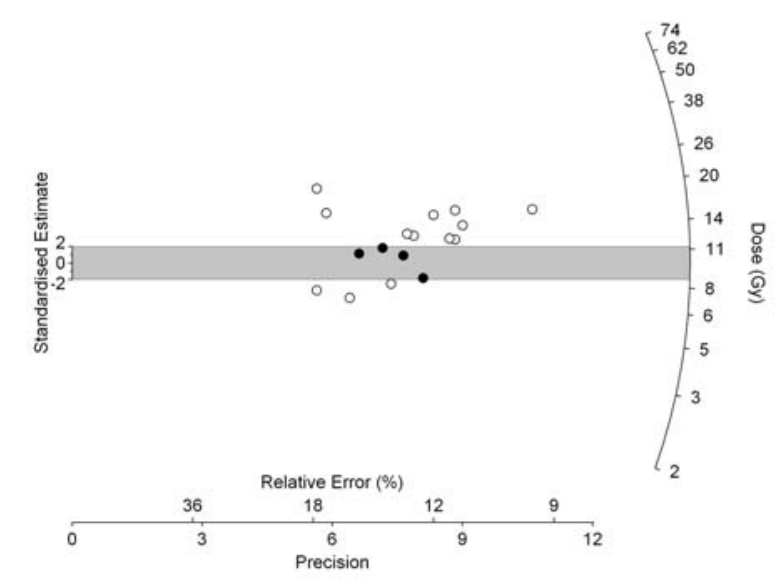

C

Fig. 7. Radial plots of the distribution of $D_{e}$. The shaded regions are centered around the equivalent dose values obtained using central age model a) KHF-1, b) KHF-2 and c) KHF-3.
Galbraith et al., 1999), then the ages with average dose rate would be $32.1 \pm 2.9 \mathrm{ka}, 31.4 \pm 4.0 \mathrm{ka}$ and $4.4 \pm 0.3 \mathrm{ka}$ respectively. Sample KHF-2 from the layer B (Fig. 3) was from the fault plane just over the foot wall block of fault F2 and inside the wedge formed between the two faults F1 and F2 (Fig. 2). This sampling location within B actually represents a portion moved upward by reverse faulting. In the pre-faulting condition location of KHF-2 would have been horizontally in layer $\mathrm{C}$, continued south eastward, but in the wedge of F1 and F2 this layer C is missing probably due to erosion that removed the layers $\mathrm{C}$ and D. These two B horizons thus had similar ages of $\sim 30 \mathrm{ka}$ within one sigma error. The age of the sample KHF-3 from top layer of scarp-derived colluvium E was $3.0 \pm 0.3 \mathrm{ka}$. The offsetting in sediments indicates reactivation of the KHF in the Holocene and that suggest that the region is neotectonically and palaeoseimically active.

\section{DISCUSSION AND CONCLUSIONS}

Three sediment layers offset by neotectonic reactivation of the Katrol Hill fault (KHF), as evidenced in the exposed cliff section in the Khari river basin, SE of Bharasar $\left(23^{\circ} 11^{\prime} 36.5^{\prime \prime} \mathrm{N}, 6^{\circ} 35^{\prime} 22.6^{\prime \prime} \mathrm{E}\right)$, Kachchh, Western India provide optical ages of $31.8 \pm 2.8 \mathrm{ka}, 28.5 \pm 3.7 \mathrm{ka}$ and $3.0 \pm 0.3 \mathrm{ka}$ using the minimum age model of Mayya et al., and $32.1 \pm 2.9 \mathrm{ka}, 31.4 \pm 4.0 \mathrm{ka}$ and $4.4 \pm 0.3$ using central age model respectively. Using luminescence chronometry of river sections, Mathew et al., (2006) inferred sesimic activity along the Kachchh Mainland Fault (KMF) during the Holocene. Activities along any of the major faults of the same basin could also trigger other faults of the same system, which is to be expected for seismically and tectonically complex rift system of Kachchh basin. The chronology of tectonically caused river incisions, channel fills and valley fill terraces along the KMF suggested incision ages to decreasing progressively from $\sim 12 \mathrm{ka}$ to $4.3 \mathrm{ka}$. Using geological evidences of decrease in topographic relief, drainage capture and drainage migration, an average uplift rate of $10 \pm 1 \mathrm{~mm} / \mathrm{y}$ along the eastern Northern Hill Region was obtained by Mathew et al., (2006). Recent GPS based instanteneous rates of crustal shortening in Kachchh are $\sim 12 \mathrm{~mm} / \mathrm{y}$ (Jade et al., 2002). The crustal shortening of whole of Kachchh actually involves the cumulative slip of all the faults, mainly of the four major faults like the KMF, IBF (Island Belt Fault), Allah Bund Fault and KHF.

The present sequence along KHF records three tectonic episodes with a few associated minor ones. Reactivation along the fault F2 (Fig. 2) could have affected the last layer E; therefore cummulative displacement on F2 at

Table 1. Details of sample code, radioactivity, dose rate, equivalent dose $\left(D_{e}\right)$ and ages obtained from two different age models.

\begin{tabular}{|c|c|c|c|c|c|c|c|c|c|c|c|c|c|}
\hline $\begin{array}{l}\text { Sample } \\
\text { no. }\end{array}$ & $\begin{array}{c}\text { Grain } \\
\text { Size }(\mu \mathrm{m})\end{array}$ & $\begin{array}{l}\text { Count rate } \\
\text { (/ksec) }\end{array}$ & $\mathrm{U}(\mathrm{ppm})$ & Th (ppm) & K (wt. \%) & $\begin{array}{c}\text { Water } \\
(\%)\end{array}$ & $\begin{array}{l}\text { Cosmic } \\
\text { ( } \mu \text { Gy/a) }\end{array}$ & $\begin{array}{c}\text { Dose Rate } \\
\text { (Gy/ka) }\end{array}$ & $\begin{array}{l}\text { De (Gy) } \\
M i n+2 \sigma\end{array}$ & $\begin{array}{l}\text { De (Gy) } \\
\text { (CAM) }\end{array}$ & $\begin{array}{c}\text { De (Gy) } \\
\text { (Mayya et al. } \\
2006 \text { ) }\end{array}$ & $\begin{array}{l}\text { Age (ka) } \\
\text { (CAM) }\end{array}$ & $\begin{array}{c}\text { Age (ka) } \\
\text { (Mayya et al. } \\
\text { 2006) } \\
\end{array}$ \\
\hline KHF-1 & $90-150$ & $6.18 \pm 0.13$ & $2.08 \pm 0.34$ & $5.19 \pm 1.21$ & $0.70 \pm 0.01$ & $5 \pm 2$ & $76 \pm 8$ & $1.54 \pm 0.12$ & $38.9 \pm 1.5$ & $49.5 \pm 2.4$ & $49.0 \pm 1.9$ & $32.1 \pm 2.9$ & $31.8 \pm 2.8$ \\
\hline KHF-2 & $90-150$ & $6.95 \pm 0.11$ & $3.09 \pm 0.43$ & $3.28 \pm 1.48$ & $0.98 \pm 0.10$ & $5 \pm 2$ & $102 \pm 10$ & $1.91 \pm 0.17$ & $42.8 \pm 4.1$ & $59.9 \pm 5.6$ & $54.5 \pm 5.2$ & $31.4 \pm 4.0$ & $28.5 \pm 3.7$ \\
\hline KHF-3 & $90-150$ & $6.77 \pm 0.10$ & $2.38 \pm 0.27$ & $5.22 \pm 0.96$ & $1.15 \pm 0.02$ & $5 \pm 2$ & $167 \pm 17$ & $2.11 \pm 0.10$ & $4.9 \pm 0.4$ & $9.3 \pm 0.5$ & $6.3 \pm 0.5$ & $4.4 \pm 0.3$ & $3.0 \pm 0.3$ \\
\hline
\end{tabular}


the site was measured as $5 \mathrm{~m}$ and that on $\mathrm{F} 1$ was $2 \mathrm{~m}$ in two separate episodes. Besides comparing the difference in displaced geometry in NW and SE parts from the two faults in Fig. 2, original horizontality in NW part was intact (see the reference contact $\mathrm{A} / \mathrm{B}$ as found at $2 \mathrm{~m}$ level). The same contact in SE part was at $9 \mathrm{~m}$ level. This matched with the cummulative displacements $(\sim 7 \mathrm{~m})$ on F1and F2 faults. The accumulated slip of these events during the past $30 \mathrm{ka}$ is $\sim 7 \mathrm{~m}$ and so the average slip rate is $0.23 \mathrm{~mm} / \mathrm{y}$. This is to be be treated as minimal estimate as evidences of major phases of erosion after each faulting event exists (Patidar et al., 2008). These estimates will be $0.22 \mathrm{~mm} / \mathrm{year}$ if we were to use the central age model.

The distribution of $\mathrm{D}_{\mathrm{e}}$ values in the histograms (Fig. 5) of the three samples indicates significant dispersion. This could be due either or both due to insufficient bleaching and heterogeneity of beta dose (Mayya et al., 2006; Chauhan et al., 2011, in print), given that the concentration of potassium in the sediments is low. We consider that the local arid- hyper arid desertic conditions and high solar insolation, should have facilitated reasonable bleaching at the time of deposition and hence consider beta dose heterogeneity as the major cause for the dispersion of ages. We have however presented both the possible age estimates in Table 1. If the ages obtained using CAM are used then the slip rate would be $0.22 \mathrm{~mm} / \mathrm{y}$. Thus, the average slip rate of the segment of KHF at the present location would be higher than the computed value of $0.22 \mathrm{~mm} / \mathrm{y}$, even if we consider the contribution of the overestimation in the age values due to insufficient bleaching of some grains to the estimated over all slip rate. Compared to the present GPS measurment and that of Mathew et al. ( 2006) it seems that the convergence rate has increased several fold over the past few ka.

\section{ACKNOWLEDGEMENTS}

The authors acknowledge Dr. S. Bhandari of the Department of Earth and Environmental Sciences, K. S. K. V. Kachchh University, Bhuj, Gujarat for his assistance in the field.

\section{REFERENCES}

Adamiec G and Aitken M, 1998. Dose-rate conversion factors: update. Ancient TL 16(2): 37-50.

Baskaran M, Despande SV, Rajaguru SN and Somayajulu BLK, 1989. Geochronology of miliolite rocks of Kutch, western India. Journal of the Geological Society of India 33: 588-593.

Biswas SK and Deshpande SV, 1970. Geologic and tectonic maps of Kachchh. Bulletin of Oil and Natural Gas Commission 7: 115116.

Biswas SK, 1974. Landscape of Kutch - A Morphotectonic Analysis. Indian Journal of Earth Science 1: 77-190.

Biswas SK, 1977. Mesozoic rock stratigraphy of Kutch. Quaterly Journal of the Geological, Mining and Metallurgical Society of India 49: $1-52$

Biswas SK and Khattri KN, 2002. A geological study of earthquakes in Kachchh, Gujarat, India. Journal of the Geological Society of India 60: 131-142.

Chauhan N, Anand S, Shinde DP, Mayya S and Singhvi AK, 2011. Single grain beta dose distribution in sediments: Effect of beta straggling and density of soil. Geochronometria, in print.

Fattahi M, Walker R, Hollingsworth J, Bahroudi A, Nazari H, Talebian M, Armitage S and Stokes S, 2006. Holocene slip-rate on the Sabzevarthrust fault, NE Iran, determined using optically stimulated luminescence (OSL). Earth and Planetary Science Letters 245: 673-684.

Fattahi M, Walker RT, Khatib MM, Dolati A and Bahroudi A, 2007. Slip-rate estimate and past earthquakes on the Doruneh fault, eastern Iran. Geophysical Journal International 168: 691-709.

Fattahi M 2009. Dating past earthquakes and related sediments by thermoluminescence methods: a review. Quaternary International 199(1-2): 104-146.

Fattahi M, Nazari H, Bateman MD, Meyer B, Sebrier M, Talebian M, Le Dortz K, Foroutan M, Ahmadi Givi F and Ghorashi M, 2010. Refining the OSL age of the last earthquake on the Dheshir fault, Central Iran. Quaternary Geochronology 5: 286-292.

Galbraith RF, Roberts RG, Laslett GM, Yoshida H and Olley JM, 1999. Optical dating of single and multiple grains of quartz from Jinmium rock shelter, northern Australia: Part I, experimental design and statistical models. Archaeometry 41: 339-364.

Jacobs Z, Wintle AG, Roberts RG and Duller GAT, 2008. Equivalent dose distributions from single grains of quartz at Sibudu, South Africa: context, causes and consequences for optical dating of archaeological deposits. Journal of Archaeological Science 35: 1808-1820.

Jade S, Mukul M, Parvez IA, Ananda MB, Kumar PD and Gaur VK, 2002. Estimates of coseismic displacement and post deformation using Global Positioning System geodesy for the Bhuj earthquake of 26 January, 2001. Current Science 82: 748-752.

Le Dortz K, Meyer B, Sebrier M, Nazari H, Braucher R, Fattahi M, Benedetti L, Foroutan M, Siame L, BourlesD, Talebian M, Bateman MD and Ghoraishi M, 2009. Holocene right-slip rate determined by cosmogenic and OSL dating on the Anar fault, Central Iran. Geophysical Journal International 179: 700-710.

Little Timothy A, Dissen Russ Van, Rieser Uwe, Smith Euan GC and Langridge Rob M, 2010. Coseismic strike slip at a point during the last four earthquakes on the Wellington fault near Wellington, New Zealand. Journal of Geophysical Research 115, DOI: 10.1029/2009JB006589.

Mathew George, Gundu Rao TK, Sohoni PS and Karanth RV, 2004. ESR dating of interfault gypsum from Katrol hill range, Kachchh, Gujarat: Implications for neotectonism. Current Science, 87(9): 1269-1274.

Mathew George, Singhvi Ashok K and Karanth Rama V, 2006. Luminiscence chronometry and geomorphic evidence of active fold growth along the Kachchh Mainland Fault (KMF) Kachchh, India: seismotectonic implications. Tectonophysics 422: 71-86, DOI 10.1016/j.tect.2006.05.009.

Mayya YS, Morthekai P, Murari MK and Singhvi AK, 2006. Towards quantifying beta microdosimetric effects in single grain quartz dose distribution. Radiation Measurements 41: 1032-1039, DOI 10.1016/j.radmeas.2006.08.004.

Morthekai P 2007. Investigation on the radiation dose distribution in natural environment and their implication in luminescence chronology, unpublished Ph.D. thesis, Gujarat University: 148 pp.

Murray AS and Wintle AG, 2000. Luminescence dating of quartz using an improved single aliquot regenerative-dose protocol. Radiation Measurements 32: 57-73, DOI 10.1016/S1350-4487(99)00253-X.

Murray AS and Wintle AG, 2003. The single aliquot regenerative dose protocol: potential for improvements in reliability. Radiation Measurements 37: 377-381, DOI 10.1016/S1350-4487(03)000532.

Nagar YC, Sastry MD, Bhushan B, Kumar A, Mishra KP, Shastri A, Deo MN, Kocurek G, Magee JW, Wadhawan SK, Juyal N, Pandian MS, Shukla AD and Singhvi AK, 2010. Chronometry and formation pathways of gypsum using Electron Spin Resonnace and Fourier Transform- Infrared Spectroscopy. Quaternary Geochronology, DOI:10.1016/j.quageo.2010.05.001

Nissen Edwin, Walker Richard, Molor Erdenebat, Fattahi Morteza and Bayasgalan Amgalan, 2009. Late Quaternary rates of uplift and shortening at Baatar Hyarhan (Mongolian Altai) with optical stimulated luminescence. Geophysical Journal International 177: 259-278.

Nissen Edwin, Walker Richard T, Bayasgalan Amgalan, Carter Andrew, Fattahi Morteza, Molor Erdenebat, Schnabel Christoph, West A. Joshua and Xu Sheng, 2009. The late Quaternary slip-rate of the Har-Us-Nuur fault (Mongolian Altai) from cosmogenic ${ }^{10} \mathrm{Be}$ and luminescence dating. Earth and Planetary Science Letters 286: 467-478.

Patidar AK, Maurya DM, Thakkar MG and Chamyal LS, 2007. Fluvial geomorphology and neotectonic activity based on field and GPR 
data, Katrol Hill Range, Kachchh, Western India. Quaternary International 159: 74-92.

Patidar AK, Maurya DM, Thakkar MG and Chamyal LS, 2008. Evidence of neotectonic reactivation of the Katrol Hill Fault during late Quaternary and its GPR characterization. Current Science 94: 338-346.

Porat N, Levi T and Weinberger R, 2007. Possible resetting of quartz OSL signals during earthquakes - evidence from late Pleistocene injection dykes, Dead Sea basin, Israel. Quaternary Geochronology 2(1-4): 272-277.

Prescott JR and Hutton JT, 1994. Cosmic ray contributions to dose rates for luminescence and ESR dating: large depths and long term variations. Radiation Measurements 23: 497-500, DOI 10.1016/1350-4487(94)90086-8.

Pucci S, De Martini PM and Pantosti D, 2008. Preliminary slip rate estimates for the Duzce segment of the North Anatolian fault Zone from offset geomorphic markers. Geomorphology 97 (3-4): 538554.
Schumn SA, 1986. Alluvial rivers response to active tectonics. National Academy Press, Washington, D.C., 80-94.

Singhvi AK, Banerjee D, Pande K, Gogte V, Valdiya KS, 1994. Luminescence studies on neotectonic events in south-central Kumaun Himalaya - a feasibility study. Quaternary Science Reviews 13: 595-600.

Singhvi AK, Chauhan N and Biswas RH, 2010. A survey of some new approaches in extending the maximum age limit and accuracy of luminescence application to archeological chronometry. Journal of Mediterranean Archaeology (in press).

Thakkar MG, Maurya DM, Raj Rachna and Chamyal LS, 1999. Quaternary tectonic history and terrain evolution of the area around Bhuj, Mainland Kachchh, western India. Journal of the Geological Society of India 53: 601- 610.

Thakkar MG, Goyal B, Patidar AK, Maurya DM and Chamyal LS, 2006. Bedrock gorges in the central mainland Kachchh: Implications for landscape evolution. Journal of Earth System Science 115(2): 249-256. 